\title{
Changes in Outbound Tourism from the Visegrád Countries to Austria
}

\author{
KUREHA Masaaki \\ Institute of Geoscience, University of Tsukuba, Tsukuba, Ibaraki 305-8571, Japan
}

\begin{abstract}
The purpose of this study is to examine the changes in outbound tourism from the Visegrád Countries (Poland, the Czech Republic, Slovakia, and Hungary) to Austria. The number of tourists from these countries to Austria has greatly increased since the late 1980s, especially during winter. A majority of these tourists used to visit cities in Austria, especially Vienna, during the socialist period. However, tourist destinations have now changed. Several areas in the Alpine region have become popular among tourists since 1990. In the province Tyrol, many winter tourists stay in the valleys with large glacial ski areas that always offer good snow conditions. Most of them travel in groups, and there are only a small number of individual travelers. Tourists come to Tyrol by chartered bus and usually opt for cheaper accommodation, when staying for five to six days. Since 1990, tourism from the Visegrád Countries to Austria has been developed on account of winter sports, however, it accounts for approximately $2 \%$ of the tourist nights in Austria. This development in tourism can be partly attributed to the accessibility from the Visegrád Countries to Austria and the fact that Austrian resorts are relatively inexpensive, compared with the other Alpine resorts in Switzerland or France. Moreover, many Alpine regions have come to need the new tourist market of the Visegrád Countries, because the regular visitor market, comprising largely German tourists, is unlikely to expand.
\end{abstract}

Key words: tourism, ski, Visegrád Countries, Austria, Tyrol

\section{Introduction}

Tourism conditions in the Visegrád Countries $^{1}$ (Poland, the Czech Republic, Slovakia, and Hungary) have changed dramatically as a result of the political and economic restructuring of former Eastern Europe that began in 1989. The political and economic circumstances prevailing between 1950 and 1989 left people in Europe with few opportunities to cross the iron curtain in either direction. During the totalitarian period, on the eastern side of the curtain, people of the Visegrád Countries tended to travel only within the former Eastern Block (Hall 1991; Jordan 1990). It was practically impossible for them to cross the border and enter Western Europe because of the difficulties faced in buying foreign currency and obtaining visas. Therefore, their main holiday destinations were coastal areas along the Adriatic Sea, the Black Sea or Lake Balaton, as well as various tourist destinations within the East- ern Block. Although it was possible for people living on the western side of the iron curtain to travel to the Eastern Block, strict travel restrictions were imposed. Only in a few exceptional cases were people from Western Europe allowed to holiday along the Adriatic Sea or Lake Balaton.

Since the 1989 revolution, however, quite new changes have been observed in tourist flow. There are two aspects to these changes. First, there has been a rapid increase in the number of tourists to the Visegrád Countries, especially from Western Europe. Second, the travel activities of people of the Visegrád Countries have also changed. The number of tourists from these countries who visit Western Europe has rapidly increased. This includes tourists who travel to these countries not only for overnight stays, but also on day trips for various purposes, especially shopping. Over ten years have passed since the transformation of the Visegrád Countries. The travel activities of the people from these countries have now diversi- 
fied and the number of outbound tourists has stabilized today. The latter change is observed in the Czech Republic (Kureha 2001).

Previous studies on this subject have primarily emphasized problems relating to the first aspect. Hall (1998) discussed some of the major elements of tourism and economic development in Central and Eastern Europe and their significance in the European context. His study primarily focuses on Central and Eastern Europe as holiday destinations mainly for tourists from Western Europe. There are only a few instances of outbound tourism from these areas. There has been considerable research on tourism in the Visegrád Countries in this context (Mariot 1993; Johnson 1995). Williams and Baláž (2002) have analyzed the economic aspects of transition economies through a discourse on the experiences of the former Czechoslovakia. Simpson (1999) has described some perspectives on urban tourism in Prague, as well as problems. Some other studies discuss tourist activity in the Visegrád Countries from the perspective of the certain visitor market (Langlois et al. 1999; Baláž and Mitsutake 1998). Köppen (2000) has discussed German tourists who visit the northern area of Bohemia for the purpose of shopping. Further, many papers have focused on domestic tourism in this area (Williams and Baláž 2001; Kurek 1996).

Conversely, a few studies, for example Hall (1998) and Kureha (2001), have analyzed outbound tourism from the Visegrád Countries to Western Europe. These studies, however, do not consider foreign tourism as a core object of analysis. Although Smeral (1993) showed the possibility of the new tourist market in Eastern Europe in the beginning of the 1990s, the analysis of the Austrian economist was performed too early to predict the activities of tourists from the Visegrád Countries.

There is insufficient research on outbound tourism from Eastern European countries. This is mainly due to the fact that there is a small tourist market based on population size and economic situation. On the contrary, the larger tourist market in Western Europe has strong potential for development of tourism in the Visegrád Countries. In fact, tourists from the Visegrád Countries do not play an important role in tourism in Western European countries. With regard to this, geographers have to consider regional differences on various scales. There will be many small regions, where tourists from the Visegrád Countries are indispensable today. The author emphasizes this regional difference, based on regional scale, in his analysis. In this context, only Böröcz (1996) examined Hungarian tourism in Austria, however, his research was only concerned with shopping tourism in Vienna.

The present study attempts to examine the new form of outbound tourism among the people of the Visegrád Countries. Specifically, the regional changes in their travel activities in Austria are analyzed. Austria is characterized not only as one of the most frequent visited destinations in Europe but also as an area located close to the Visegrád Countries.

The following three analyses are described in this study. First, the changing trend of tourists from the Visegrád Countries to Austria is analyzed using published data from the statistical office of Austria, Statistik Austria. The travel activity of tourists who stay overnight is examined from various perspectives, such as those of annual tourist development, seasonal frequency, the length of stay, and use of accommodations. Second, the changes in tourism are examined in greater detail on a regional scale, using unpublished data from Statistik Austria. Austria is divided into 99 political counties, the Politische Bezirke. The second analysis identifies the regional characteristics of tourists from the Visegrád Countries traveling across Austria with regard to several travel indexes. Third, their travel activities are further analyzed on the most detailed regional scale, i.e. the commune (Gemeinde) scale. Specifically, the regional differences in the areas visited are observed by commune level in the province Tyrol, Land Tirol. This analysis was performed using the published and unpublished data from the provincial government of Tyrol. Through these three analyses, this paper attempts to study outbound tourism from the Visegrád Countries to Austria, discussing regional differentiation. 


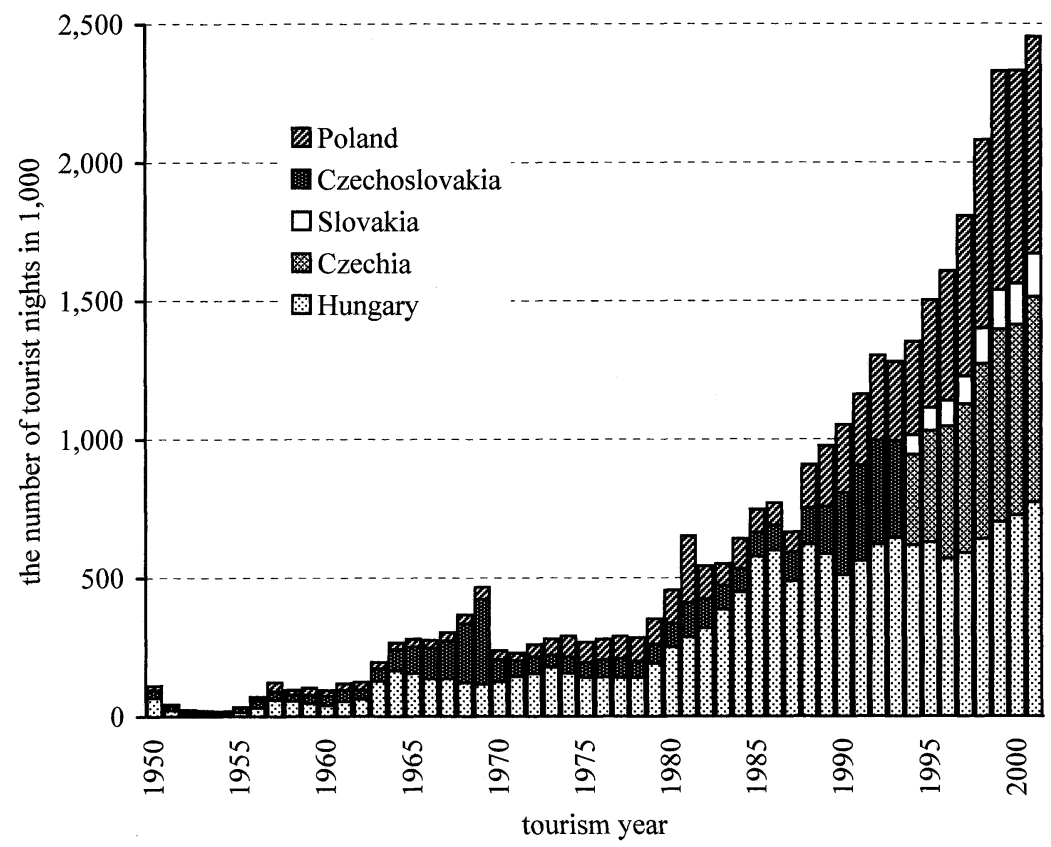

Figure 1. Development of tourist nights in Austria from the Visegrád Countries 1950-2001.

Note: Each tourism year represents 12 months from November of the last year to October of the concerned year.

Source: Statistik Austria: Tourismus in Österreich and Fremdenverkehr in Österreich (annual).

\section{Development in Tourism from the Visegrád Countries to Austria}

Figure 1 represents the development in the total number of tourist nights in Austria from the Visegrád Countries by country. Until 1980, this figure was less than 500,000 . Since then, the number has rapidly increased, namely it reached one million in 1990 and 2.3 million in 2000. The increase during the 1980s was mainly due to the increase in the number of tourists from Hungary, which was on account of Hungary's advanced policy on transborder movement of people. For example, in 1979, Hungary discontinued the visa duty for travel to Austria. The number of tourists from the Czech Republic, Slovakia, and Poland has risen only since 1989 , when the political and economic transformation began. Today, approximately 0.7 million nights are spent in Austria by tourists from Poland, Hungary, and Czechia, annually and respectively.

The number of visitors from the Visegrád Countries comprised only a small fraction of total Austrian tourism. During the 1960s and
1970 s, the proportion of tourist nights from the Visegrád Countries remained low at $0.5 \%$. This proportion has rapidly increased since 1980 and especially since 1990. However, tourist nights spent by the people from the Visegrád Countries comprised only $2 \%$ of the total tourist nights spent in Austria in 2001.

The seasonal proportion of tourists has also changed. Figure 2 demonstrates the development in the number of tourist nights from the Visegrád Countries to Austria by half-years. During the socialist era, there was a large number of tourists in summer. Until the early 1990 s, tourist nights in the summer half-year (May to October) surpassed those in the winter half-year (November to April). However, in 1994, the number of tourists in winter exceeded that in summer and this figure has been steadily increasing since then (Figure 2). Today, about 1.6 million nights are spent by tourists from the Visegrád Countries in winter, whereas those spent in summer are only half this figure, namely 0.8 million nights. The proportion of tourist nights in the winter half-year was only $36 \%$ in 1990 . However, this figure increased to 


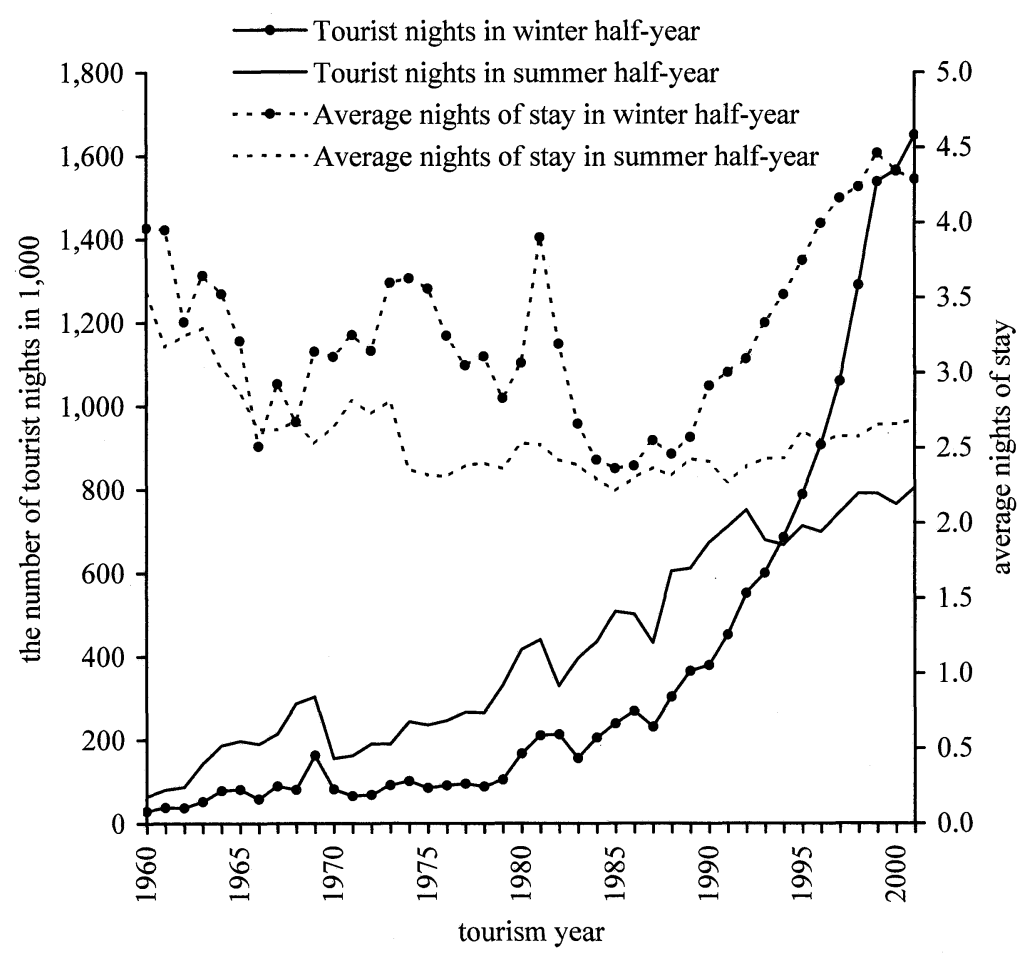

Figure 2. Development of tourist nights and average length of stay from the Visegrád Countries to Austria by half-year 1960-2001.

Note: 1. Each tourism year represents 12 months from November of the last year to October of the concerned year.

2. Winter half-year represents 6 months from November of the last year to April, and the summer from May to October.

Source: Statistik Austria: Tourismus in Österreich and Fremdenverkehr in Österreich (annual).

$67 \%$ in 2000 . This trend is also observable in the changes in the monthly proportions of tourist nights (Figure 3). Tourist visits peaked only in the summer months (July to September) in 1980 and 1990. However, the monthly frequency has changed since 1990. In 2000, a remarkable peak is observed in winter (January to March) with a small peak in summer.

Tourists from the Visegrád Countries also have distinctive features with regard to their length of stay. Their stays were generally shorter than those of tourists from the main countries of tourist origin, such as Germany and the Netherlands. The average length of stay of German tourists was 7.1 nights in 1961, 8.6 nights in 1971, 7.6 nights in 1981, 6.1 nights in 1991, and 5.2 nights in 2001. The same figures for tourists from the Visegrád Countries were only $3.4,2.9,2.8,2.5$, and 3.6 nights, respectively. While the length of stay of German tourists has decreased over the last 30 years, that of tourists from the Visegrád Countries has increased over the last ten years. In particular, for tourists from Visegrád Countries, the average length of stay in winter was 4.3 nights, while that of summer was 2.7 nights in 2001 . Polish winter tourists stayed the longest, namely an average of 5.2 nights in the same year.

Compared with tourists from other countries, tourists from the Visegrád Countries exhibit a distinctive trend in the use of accommodations. Table 1 represents the proportions of nights spent by tourists from the Visegrád Countries as well as by all tourists to Austria, by category of lodging facilities. The figure for nights spent at four-or five-star hotels was the highest when the total number of tourists was considered; people from the Visegrád Countries, most often, stay at three-star hotels. During the socialist 


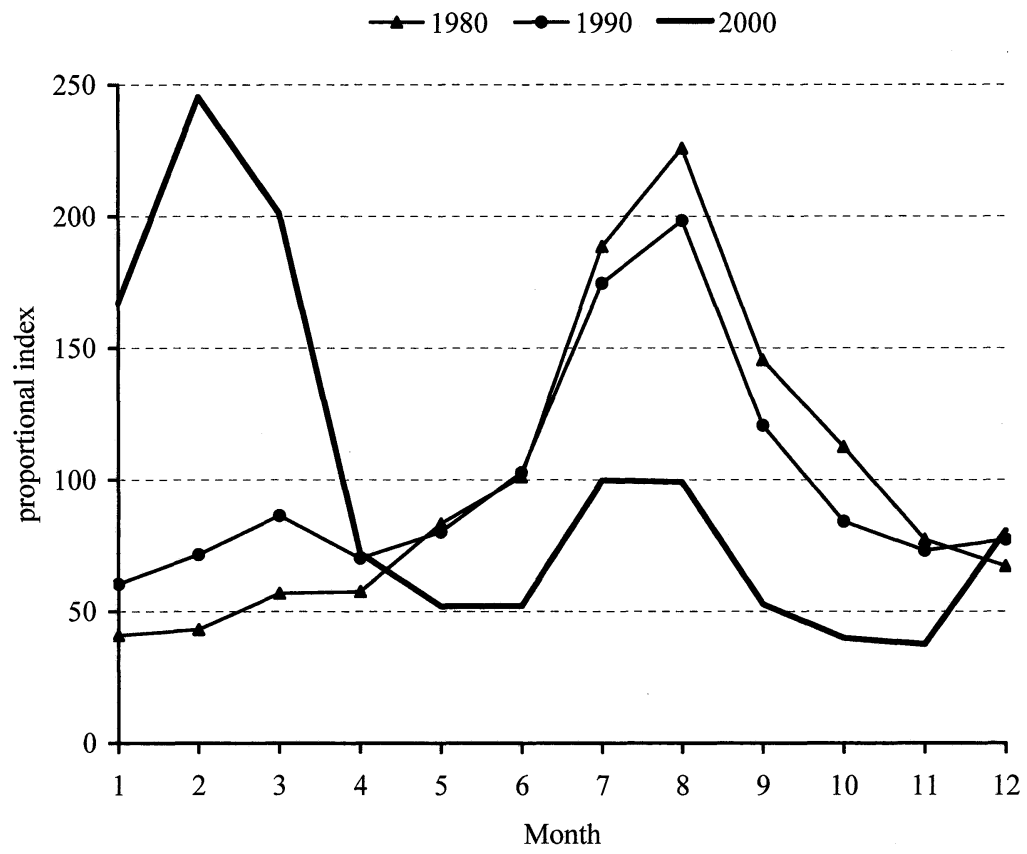

Figure 3. Monthly proportional changes of tourist nights in Austria from the Visegrád Countries, 1980, 1990 , and 2000.

Note: Proportional index $=100$ (monthly nights)/(annual nights $/ 12$ ).

Source: Statistik Austria: Tourismus in Österreich and Fremdenverkehr in Österreich (annual).

Table 1. Proportion of tourist nights by category of lodging facilities

\begin{tabular}{|c|c|c|c|c|c|c|c|c|}
\hline \multirow{2}{*}{$\begin{array}{l}\text { Category of } \\
\text { accommodation }\end{array}$} & \multicolumn{4}{|c|}{ Visitor from Visegrád Countries } & \multicolumn{4}{|c|}{ Total visitor in Austria } \\
\hline & 1981 & 1991 & 1996 & 2001 & 1981 & 1991 & 1996 & 2001 \\
\hline Hotels $5 / 4$ stars & 14.3 & 15.1 & 16.6 & 16.6 & 13.2 & 18.6 & 23.5 & 28.3 \\
\hline Hotels 3 stars & 24.5 & 21.2 & 21.4 & 23.0 & 18.2 & 22.5 & 23.0 & 23.4 \\
\hline Hotels $2 / 1$ stars & 36.0 & 25.8 & 20.0 & 12.7 & 27.8 & 20.6 & 16.4 & 11.4 \\
\hline Small accommodations ${ }^{\text {a) }}$ & 6.2 & 12.5 & 13.0 & 10.1 & 23.0 & 15.7 & 11.9 & 9.0 \\
\hline Small apartments ${ }^{\mathrm{b})}$ & c) & c) & c) & 16.1 & c) & c) & c) & 10.9 \\
\hline Campsite & 11.6 & 9.2 & 4.7 & c) & 5.4 & 5.3 & 4.4 & c) \\
\hline Others & 7.4 & 16.2 & 24.3 & 21.5 & 12.4 & 17.3 & 20.8 & 17.0 \\
\hline Tourist nights in 1,000 & 680 & 1,174 & 1,631 & 2,499 & 121,139 & 130,073 & 112,936 & 115,111 \\
\hline
\end{tabular}

Note: a) Small accommodations mean facilities that have less than 11 beds.

b) Small apartments mean facilities that have less than 11 beds.

c) Data in corresponded category are not available.

Source: Statistik Austria: Tourismus in Österreich and Fremdenverkehr in Österreich (annual).

era, they used to opt for cheaper accommodation such as in one-, two-, or three-star hotels, or stay at campsites. This trend is still observed indicating a strong preference for cheaper facilities; for example small apartments, Ferienwohnungen, and others including large apartments, youth hostels, etc., as shown in Table 1. Apartments have been developed as lodging facilities for long-staying tourists to Austria and are available as accommodation, where people can cook their own meals and maintain their privacy.

\section{Regional Characteristics of the Tourists from the Visegrád Countries to Austria}

Most tourists from the Visegrád Countries 


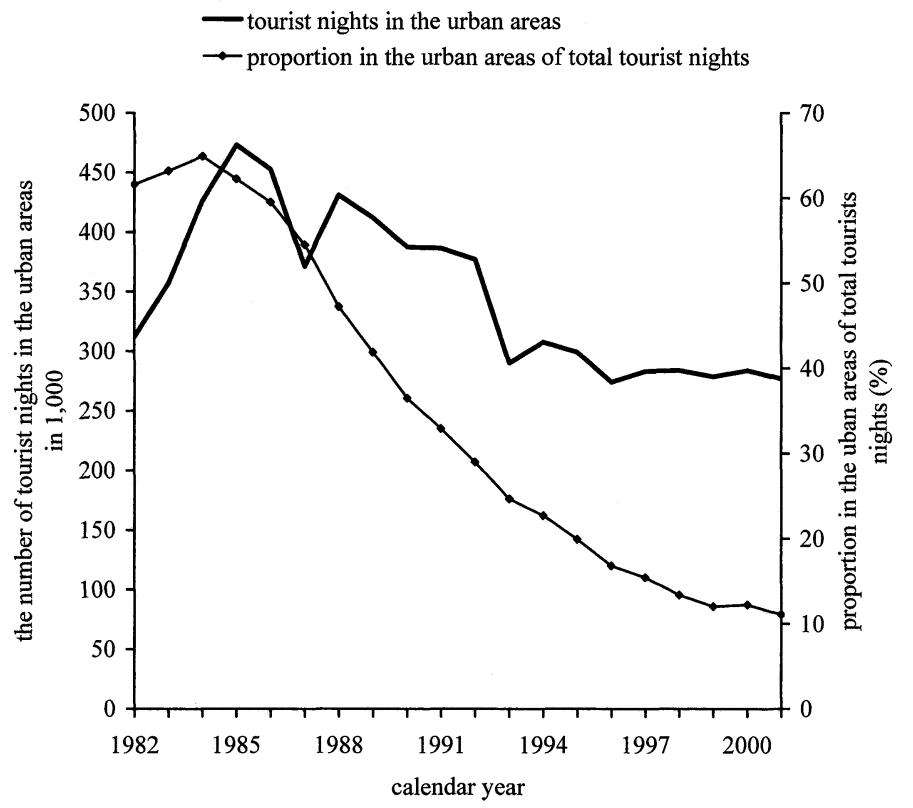

Figure 4. Changes in urban tourism from the Visegrád Countries to Austria 1982-2001. Source: Statistik Austria: Tourismus in Österreich and Fremdenverkehr in Österreich (annual).

used to visit Austrian cities during the socialist era. Figure 4 illustrates the number of tourist nights spent in the urban areas in Austria. The Austrian statistical office has been investigating urban tourism only since 1982 . Urban tourism used to be the dominant form of tourism among people from the Visegrád Countries during the 1980s, because the proportion of nights spent by tourist from these countries in urban areas was more than 50\%. These tourists especially concentrated in Vienna, the capital of Austria. Figure 5, which is based on unpublished data from the Austrian statistical office, represents changes in the regional pattern of nights spent by tourist from the Visegrád Countries, by political county in Austria. In the tourism year $1979 / 80$, the number of tourists in Vienna was remarkably high. The major cities in Austria, such as Salzburg, Graz, and Innsbruck also recorded a relatively large proportion of tourist nights from the Visegrád Countries. As mentioned above, tourists from Hungary accounted for more than half the total tourist nights in the 1980s, not only for Vienna but also for the whole of Austria.

However, tourist destinations have dramatically changed since 1990 . Urban tourism has been decreasing not only in terms of its share in total tourism but also in the number of tourist nights (Figure 4). The proportion of urban tourists was only about $10 \%$ of the total visitors from the Visegrád Countries in 2001. This trend is clearly shown in Figure 5. The regional distribution of tourist nights shows a transitional pattern in the tourism year 1989/90, when the political and economic transformation had just begun in Eastern Europe. Although urban tourism was still dominant at the time, especially in Vienna, the trend of dispersion into other areas had already emerged during the early 1990s. During this period, several areas in the Alpine region were becoming popular tourist destinations. Conversely, the number of nights spent in Vienna by tourists from the Visegrád Countries decreased and, consequently, Vienna's relative position fell significantly. The county Zell am See in the province Salzburg attracted the maximum number of visitors from the Visegrád Countries, recording approximately 350,000 nights (Figure 5).

A clear regional pattern can be observed with regard to nights spent by tourists from the Visegrád Countries when analyzed by their origin. Tourists from Hungary frequently visit 
Tourist nights in 1,000

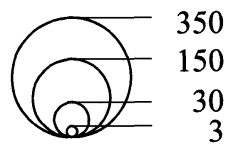

Border of the Alps

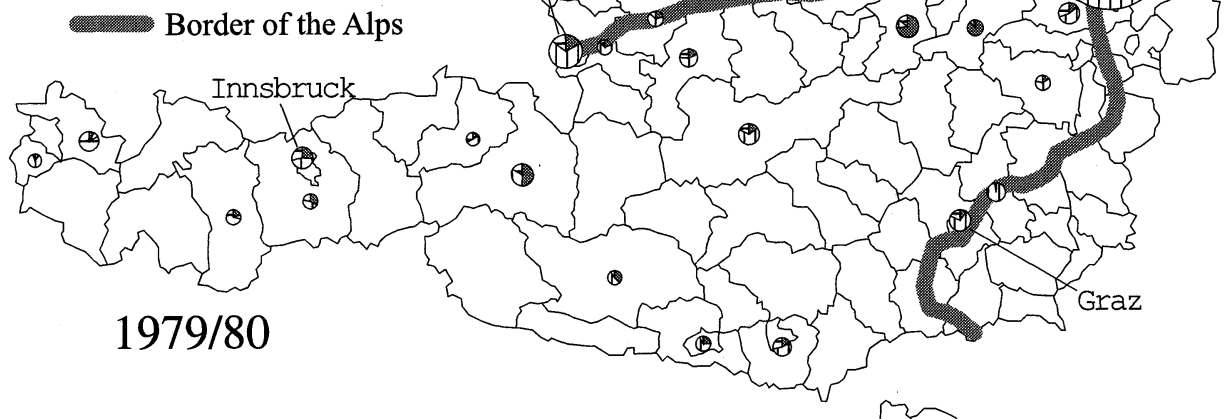

Origin of country for $1979 / 80$ and $1989 / 90$

Poland हा110 Czechoslovakia

Hungary
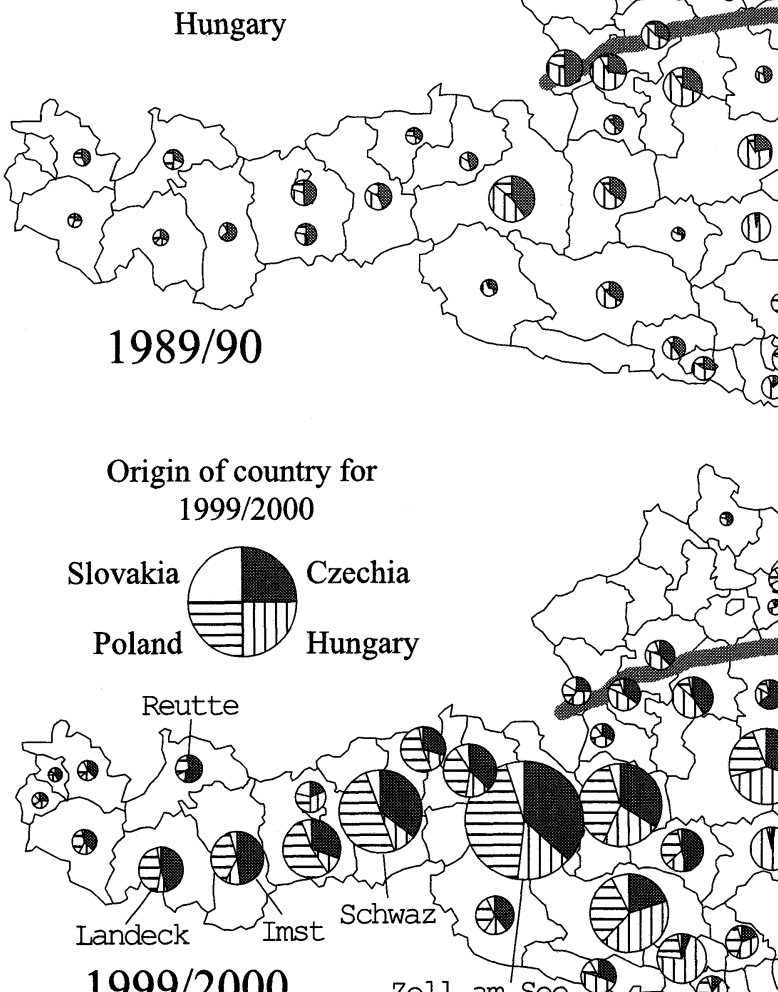

$1999 / 2000$ Zell am See

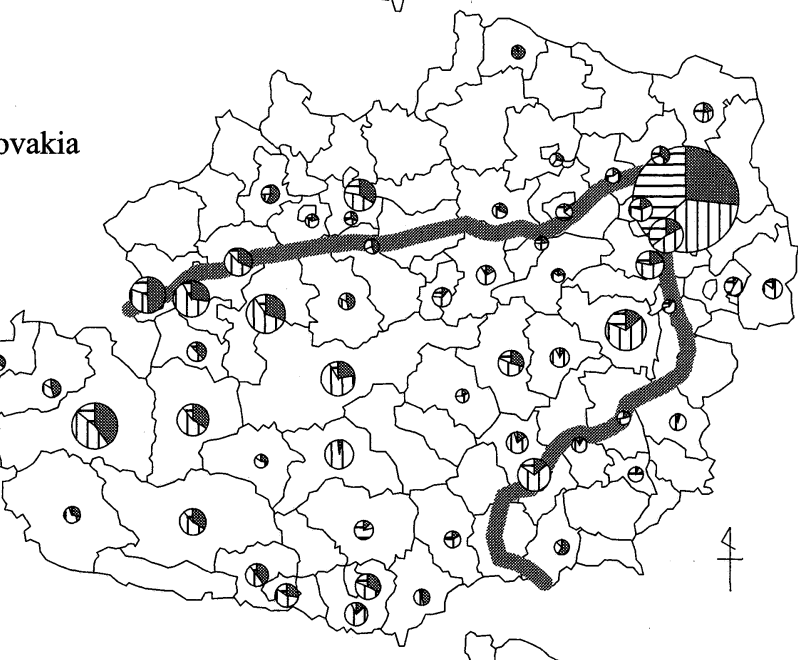

3 Vienna

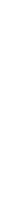


Styria and Carinthia in the eastern part of Austria, while those from the Czech Republic and Poland visit places in provinces Salzburg and Tyrol in western Austria.

Compared with the regional pattern of the total number of tourists in Austria, there is a relatively large number of tourists from the Visegrád Countries who visit eastern Austria. Thus, this figure is concentrated in the eastern region. There are many regional differences in the Eastern Alps. The east-west difference has been characterized as being the most distinctive one. The western part of the Eastern Alps has high mountain ranges and many large, developed resorts, which are relatively expensive (Kureha 1995). On the other hand, the mountains in the eastern part are relatively low and the resorts are less expensive. Tourists from the Visegrád Countries choose their destinations based on the rates. The importance of visitors from the Visegrád Countries also differs regionally. The percentage of their nights of total tourist nights is generally higher in the eastern counties than in the western. There are relatively many counties in the eastern part of the Eastern Alps, for which the figures exceed $10 \%$ in the winter half-year $1999 / 2000$. However, the average value for province Tyrol, in the same period, remains under $2 \%$.

The seasonal pattern of tourist nights also changed in the 1990s. As shown above, the number of tourists in summer was much larger than that in winter until 1990. Since then, winter guests have become dominant. Figure 6 represents the annual proportion of nights spent by tourists from the Visegrád Countries for the winter half-year in Austria by county. In $1979 / 80$, summer tourist nights of all counties exceeded those in the winter half-year, however the only exception was county Imst in Tyrol, where the number of tourist nights was only less than 4,000 in the tourism year (Figure $5)$. The number of counties, in which the proportion of winter tourist nights exceeded $50 \%$, increased to six in 1989/90. Those counties were mainly located in the eastern part of the Austrian Alps. In 1999/2000, the proportion of winter tourist nights exceeded $65 \%$ in nearly all counties in the Alpine region (Figure 6).
These changes in destination and seasonal variations are related to the changes in travel purpose or tourist activities from the Visegrád Countries to Austria. During the socialist era, urban areas in Austria were the main destinations. Therefore, shopping, business, visiting museums, or sightseeing used to be the purpose of visits from the Visegrád Countries. Since the early 1990s, however, winter sports have become the main attraction, as can be inferred from the concentration of tourists in the Alpine region during the winter season. Furthermore, since they come to Austria for their winter vacation, the length of their stay has generally increased as described above.

\section{Regional Characteristics of the Tourists from the Visegrád Countries to Tyrol}

In this section, the regional pattern of tourists from the Visegrád Countries to the province Tyrol is analyzed by commune. Figure $7 \mathrm{dem}$ onstrates the distribution of tourist nights from the Visegrád Countries in Tyrol by commune and country of origin. This figure is based on unpublished data from the provincial government office of Tyrol, Amt der Tiroler Landesregierung. In the tourism year 1992/93, Tyrol recorded a total of 45 million tourist nights. Tourists from the Visegrád Countries comprised only $0.38 \%$ of total tourist nights with 0.17 million nights. Only 14 communes in the province recorded more than 2,000 nights. The most frequently visited commune was Pitztal, followed by Innsbruck-City and Tux in the Ziller valley.

The number of tourist nights spent by people from the Visegrád Countries greatly increased to 0.57 million in $1999 / 2000$, whereas the total number recorded in Tyrol was 40 million. The total number of tourist nights in Tyrol fell during the 1990s, due to a decrease in the number of summer tourists. Therefore, the relative share of tourists in Tyrol from the Visegrád Countries grew to $1.42 \%$. The number of communes that recorded over 2,000 tourists nights from the Visegrád Countries also increased to 56 in 1999/2000.

A distinctive pattern can be observed in the regional distribution of tourist nights analyzing by tourists from the Visegrád Countries. 


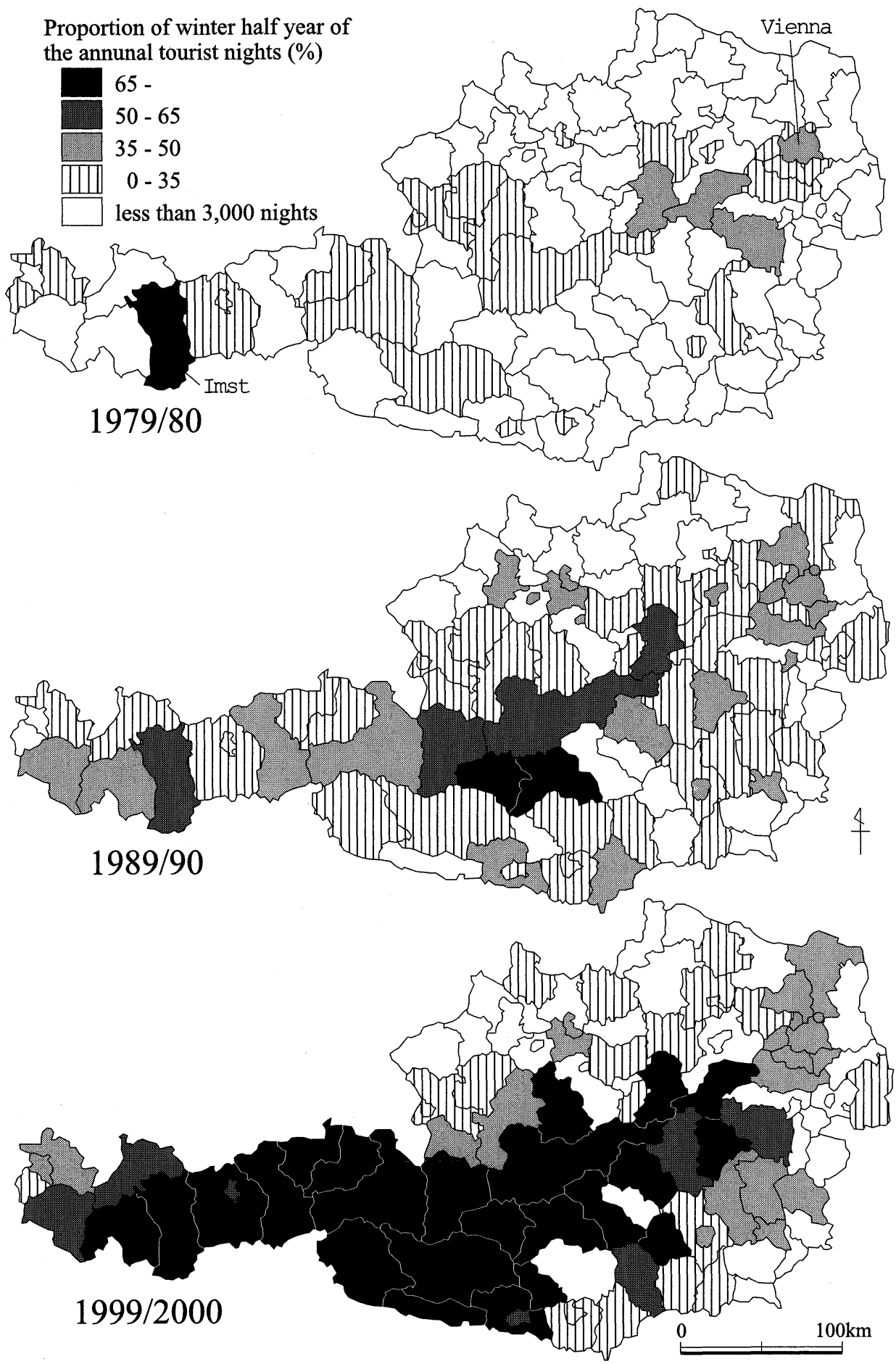

Figure 6. Proportion of winter half year in tourist nights from the Visegrád Countries in Austria by county, 1979/80, 1989/90, and 1999/2000.

Note: 1979/80 means from November 1979 to October 1980. Source: Unpublished data from Statistik Austria. 

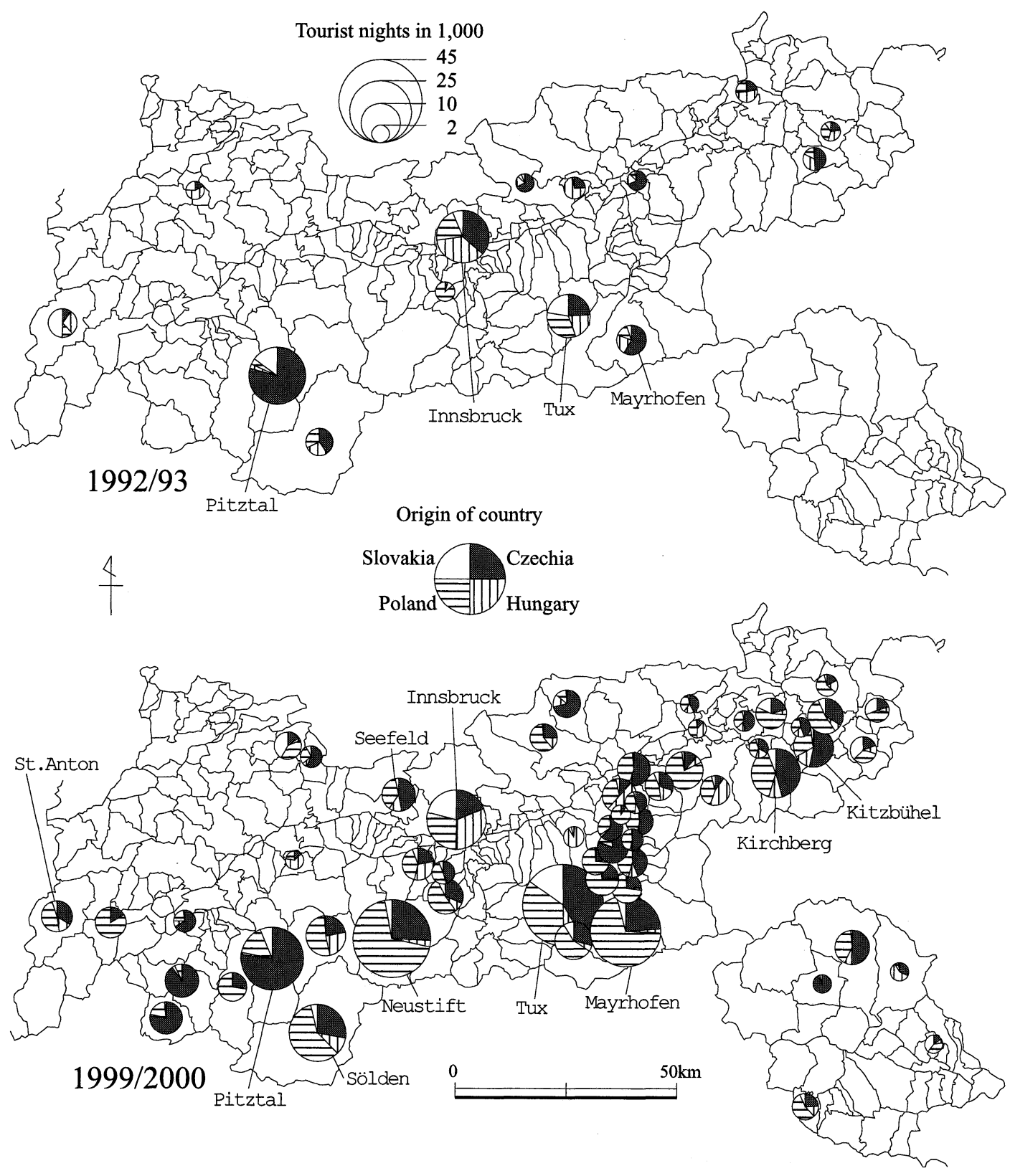

Figure 7. Distribution of tourist nights from the Visegrád Countries in Tyrol by origin, 1992/93 and $1999 / 2000$.

Note: 1 . Communes that have over 2,000 tourist nights are only represented.

2. 1992/93 means from November 1992 to October 1993.

Source: Unpublished data from Amt der Tiroler Landesregierung.

The distribution indicates a concentration in some regions. Many tourists stay in the valleys with ski areas on glacier, such as Pitztal, Ötztal, Stubaital, and Zillertal. Specifically, communes located in valleys with a glacier receive a large number of tourists, for example Pitztal in the Pitz valley, Sölden in the Ötz valley, Neustift in the Stubai valley, and Tux and Mayrhofen in the Ziller valley. In particular, there is a clear concentration of tourist nights in the Ziller val- 
ley. Glacial ski areas are characterized as large ski areas with normal ski slopes in winter and always offer good snow conditions (Haimayer 1987). On the other hand, there are relatively many tourists in the Kitzbühel region, where Kirchberg in Tirol, the next commune of Kitzbühel, received the most tourist nights.

As shown above, the regional distribution of nights spent by tourists from the Visegrád Countries is different from that of nights spent by all tourists in total in Austria. This trend also exists in Tyrol. Compared with the distribution of total tourist nights, that from the Visegrád Countries is concentrated in the county Schwaz, including the Ziller valley region. Conversely, there are fewer tourists in the counties Landeck and Reutte, which are located in the western part of Tyrol.

The majority of nights in Tyrol are spent by tourists from Poland and Czechia (Figure 7). The figure for Poland reached 0.25 million in 1999/2000, and that for Czechia was 0.21 million. Conversely, there are only a few tourists from Hungary and Slovakia, who spent 67,000 and 37,000 nights respectively. This is because tourists from those countries visit the eastern part of Austria more often (Figure 5).

The proportion of winter tourist nights of the annual total has also been increasing in Tyrol. The figure with regard to all tourists from the Visegrád Countries reached 54\% in 1992/93, but it rose to $73.3 \%$ in $1999 / 2000$. In particular, the proportion of Polish tourists exceeded $80 \%$, whereas that of Czech, Slovak, and Hungarian tourists was 69,61 , and 55\% respectively. The dominance of winter tourists can be seen in the most frequently visited regions that have large ski areas.

The length of stay of tourists from the Visegrád Countries is not short, compared with that of German and Dutch tourists. This tendency is particularly sharp during winter. The average number of nights spent by winter tourists from the Visegrád Countries was 5.4 in 1999/2000. Polish tourists stayed for 6.3 nights, whereas German and Dutch tourists stayed for 5.5 and 6.6 nights, respectively. In summer, however, the length of stay of tourists from the Visegrád Countries was shorter than that of all tourists in Tyrol, i.e. under 4 nights.
On the other hand, German and Dutch tourists spend nearly a week in Tyrol during summer.

Most tourists from the Visegrád Countries visit Tyrol to ski. There are many skiers in Poland and the Czech Republic, who tend to choose places with large ski areas that always offer good snow conditions. Of course, the Visegrád Countries have many ski areas in their mountain ranges, for example Tatra Mountains between Poland and Slovakia and Krkonoše (Riesengebirge in German) between Poland and Czechia. Most of the ski areas, however, have only small ski slopes and relatively unsophisticated equipment. Although people in the Visegrád Countries can visit the ski areas in their own countries, many skiers prefer to stay in the large Alpine ski resorts, since they offer many refined and fashionable facilities (Kureha 1995). This travel has become possible since 1989 . On the other hand, there are not as many skiers in Hungary because the country has very few ski areas. Therefore, many skiers in Hungary are less adept at skiing and mostly visit small-scale ski resorts located in the eastern part of Austria.

Most Czech and Polish tourists travel in groups, and there are only a small number of individual travelers. These group travels are normally organized by travel agencies. Therefore, as shown in Figure 7, we can observe a concentration of tourists in some specific municipalities from particular countries. Many travel agencies in the Visegrád Countries organize winter tours for the locals. The main destination of such tours is not the most famous urbanized ski resorts in Austria, such as Kitzbühel, St. Anton am Arlberg, Seefeld, or Lech, but the winter resorts that offer relatively inexpensive facilities. While most accommodation arrangements in the former resorts are in the form of luxury hotels, the latter resorts normally offer a number of facilities at rates that range from expensive to economical. Travel agencies in Poland or Czechia cooperate with cheaper accommodations as well as a chartered bus. They offer ski tours at a lower price, including lodging, breakfast, and transportation expenses for a round trip. The inclusive price varies according to the time of the visit; for example, a tour from Prague to Pitztal or 
Tux in the Ziller valley does not cost more than 400 Euros for six days. Further, some tourists carry food from their country in order to reduce their expenditure. They do so because prices in Austria are higher than those in their own country.

In Tyrol, the total number of tourists dramatically increased during the 1960 s and 1970s. Furthermore, the number of tourists in winter also increased during the 1980s. Most of the tourists came from Western Europe, i.e. from Germany, the Netherlands, United Kingdom, France, and Switzerland. In the last ten years, however, there has been no significant increase in the number of tourists from those countries to Tyrol. Therefore, tourism-related industries in Tyrol currently have to view Eastern Europe as a new tourist market. Many people from the Visegrád Countries as well as Slovenia or other countries in Eastern Europe that receive snowfall are interested in winter sports. The Tyrol Tourist Board, Tirol Werbung, has identified winter visitors from Eastern Europe as a new target group since the early 1990s. The Tourism Office has made tourist information available on the Internet in Polish and Czech languages since around 1998. The Board also creates tourist brochures in Eastern European languages and distributes them at various tourism fairs in the Visegrád Countries. Many local tourist boards at the commune level have also made similar attempts. The Communal Tourist Board of Pitztal, Tourismusverband Pitztal, in the Pitz valley has advertised in Poland and Czechia since around 1990, focusing on the resorts with glacial ski area. Therefore, Pitztal attracted many tourists even in 1992/93 (Figure 7). The Tourist Board is now advertising at tourism fairs not only in Poland and Czechia, but also in Slovenia, which is considered the newest market for tourists to Pitztal.

\section{Conclusions}

The purpose of this study was to examine outbound tourism by the people of the Visegrád Countries to Austria, analyzing three regional dimensions; national level, county level in Austria, and commune level in Tyrol.
During the socialist era, only a small number of tourists from the Visegrád Countries visited Austria. However, the number has greatly increased since the end of the 1980s, when a process of political and economic transformation began. Today, approximately 0.7 million nights per annum are spent in Austria by tourists from Poland, Hungary, and Czechia, respectively. The development in tourism has been based on the increasing number of tourists in winter, whereas summer was the main tourist season during the socialist era. Their length of stay in Austria, that was generally shorter than that of the other tourists before 1989, has become longer, especially in winter. Tourists from the Visegrád Countries exhibit a distinctive trend in the use of accommodation. They tend to choose cheaper accommodation in Austria.

With regard to the analysis of county level in Austria, there are remarkable changes in the destinations of tourists from the Visegrád Countries. Most of them visited urban areas in Austria during the socialist era. Tourists who stayed for shorter periods of time in Austrian cities, especially Vienna, visited these regions primarily for sightseeing or on business. Since 1990, the dominance of urban tourism has been decreasing. On the contrary, today, most tourists frequently visit several destinations in the Alpine region during winter. Compared with the regional pattern of the total number of tourists in Austria, there is a relatively large number of tourists from the Visegrád Countries who visit central and eastern parts of Austria, where the mountains are relatively low and the resorts are less expensive.

In Tyrol, the number of tourists from the Visegrád Countries has also increased. A distinctive pattern can be observed in the regional distribution of their destination. They tend to visit certain specific places in Tyrol, especially places in the valleys with glacial ski areas that always offer good snow conditions. The length of their stay in winter has become relatively longer. Czech and Polish people prefer to travel in groups, and there are only a small number of individual travelers. These tourists come to Tyrol by chartered bus and normally opt for cheaper accommodation for five or six days. 
Such travel is usually organized by travel agencies in the Visegrád Countries.

Tourism for the purpose of winter sports by people from the Visegrád Countries has been developed in Austria since 1990, though its share is only approximately $2 \%$ of all tourist nights in Austria. For some regions, however, the Visegrád Countries have become one of the important tourist markets, because the regular visitor market, consisting mainly of German and Dutch tourists, is unlikely to expand. Therefore, tourist boards at various regional levels have made efforts to access the new tourist market in Eastern Europe.

This development is also caused by the diverse travel activities of people in the Visegrád Countries. Their travel activities were very limited during the socialist era. After 1989, however, they have been able to choose their travel destinations due to the trend of increased incomes. During the socialist era, those who wished to ski could only visit winter resorts in Eastern Block countries. The collapse of the iron curtain in 1989 made it possible for them to visit large Alpine ski resorts, which offer more refined facilities than resorts in Eastern Europe. Furthermore, skiing in Austrian resorts has now become a status symbol among people in the Visegrád Countries.

Although other Alpine countries such as Switzerland, France, and Italy also have many ski resorts, the number of tourist nights spent in Switzerland by people from the Visegrád Countries only reached 0.35 million in 2000 . This is partly due to the geographical position of these countries, being located far from the Visegrád Countries. Furthermore, the rates offered by the resorts in these countries are generally higher than those in Austrian resorts. As a result, Austria now receives many ski tourists from the Visegrád Countries.

There are regional differences in the areas visited by tourists from the Visegrád Countries and those visited by all tourists, not only in Tyrol but also across Austria. The central and eastern parts of Austria receive a much larger number of tourists from the Visegrád Countries than the western part, where German and Dutch tourists form the majority. The price difference between Austrian resorts is the rea- son for this regional differentiation. In Tyrol, on the other hand, winter tourists from the Visegrád Countries are concentrated in certain specific regions that have glacial ski areas. These are not the most famous, urbanized ski resorts in the Alps, but a diverse range of accommodation is available with regard to price there. The predominance of group travel also affects the uneven regional distribution of winter tourists from the Visegrád Countries.

This study analyzed development of outbound tourism from the Visegrád Countries to Austria. This development is mainly based on the economic transformation of those countries and their geographical position. Furthermore, the regional differentiation in their destination is attributed to economic differentials between the Visegrád Countries and West-European countries. In the near future, the income levels of these countries will certainly become higher. There will then be another shift in outbound tourism from the Visegrád Countries to Austria.

\section{Acknowledgments}

The author would like to thank Dr. Peter Haimayer, University of Innsbruck, for supporting field survey in Tyrol. Part of this study was supported by the Grant-in-Aid for Scientific Research by the Japan Society for the Promotion of Science (1999-2002), No. 11691070 , headed by Prof. Koji Kobayashi, Gifu University.

(Received 10 November 2003) (Accepted 20 December 2003)

\section{Notes}

1. The Visegrád Countries (Poland, the Czech Republic, Slovakia, and Hungary) are characterized as the countries directly neighboring Western Europe. Historically, the Visegrád group originated in 1335, when the Czech, the Polish and the Hungarian kings held a meeting in the Hungarian city of Visegrád to conclude an alliance with the Hapsburg Empire. In 1991 , the heads of state or governments of these four countries held a summit in the same city. Since then, these countries have been called the Visegrád Countries. The purpose of the summit was to establish co-operation between these states in order to further the process of European integration. 


\section{References}

Baláž, V., and Mitsutake, M. 1998. Japanese tourists in transition countries of Central Europe: Present behavior and future trends. Tourism Management 19: 433-443.

Böröcz, J. 1996. Leisure migration: A sociological study on tourism. Oxford: Pergamon.

Haimayer, P. 1987. Aspects écologiques, économiques et sociaux du ski sur glacier en Autriche. Revue de Géographie Alpine 75: 141-156.

Hall, D. R. 1991. Evolutionary pattern of tourism development in Eastern Europe and the Soviet Union. In Tourism and economic development in Eastern Europe and the Soviet Union, ed. D. R. Hall, 79-115. London: Belhaven.

Hall, D. R. 1998. Central and Eastern Europe: Tourism, development and transformation. In Tourism and economic development: European experiences, $3^{\text {rd }}$ ed., ed. A. M. Williams and G. Shaw, 345373. Chichester: Wiley.

Johnson, M. 1995. Czech and Slovak tourism: Patterns, problems and prospects. Tourism Management 16: 21-28.

Jordan, P. 1990: Die Entwicklung der Fremdenverkehrsströme in Mitteleuropa (1910-1990) als Ausdruck politischer und wirtschaftlicher Veränderungen. Mitteilungen der Österreichischen Geographischen Gesellschaft 132: 144-171.

Köppen, B. 2000. Auswirkungen des Einkaufstourismus im nordböhmischen Grenzraum. Europa Regional 8(2): 19-31.
Kureha, M. 1995. Wintersportgebiete in Österreich und Japan. Innsbruck: Innsbrucker Geographische Studien, Bd. 24.

Kureha, M. 2001. Changes of inbound and outbound tourism in the Czech Republic through the Velvet Revolution. Tsukuba Studies in Human Geography 25: 1-36. (JE)

Kurek, W. 1996. Agriculture versus tourism in rural areas of Polish Carpathians. Geojournal 38: 191196.

Langlois, S. M., Theodore, J., and Ineson, E. M. 1999. Poland: In-bound tourism from the UK. Tourism Management 20: 461-469.

Mariot, P. 1993. Tschechoslowakei, Teil II. In Perspektiven des Fremdenverkehrs im östlichen Mitteleuropa, ed. P. Jordan and E. Tomasi, 37-47. Wien: Arbeitskreis für Regionalforschung.

Simpson, F. 1999. Tourist impact in the historic centre of Prague: Resident and visitor perceptions of the historic built environment. The Geographical Journal 165: 173-183.

Smeral, E. 1993. Emerging Eastern European tourism markets. Tourism Management 14: 411-418.

Williams, A. M., and Baláž, V. 2001. From collective provision to commodification of tourism? Annals of Tourism Research 28: 27-49.

Williams, A. M., and Baláž, V. 2002. The Czech and Slovak tourism: Conceptual issues in the economic analysis of tourism in transition. Tourism Management 23: 37-45.

(JE): written in Japanese with English abstracts 